\title{
Evaluation the Efficacy of Immunotherapy in Treatment of Bronchial Asthma
}

\author{
*Seham El-Mansi, ${ }^{* *}$ Abd Allah El-Bialy, ${ }^{* * *}$ Mohsen El-Shafey, ${ }^{*}$ Shaimaa Mohamed \\ Ebrahim El-Sayed \\ Zoology Department, Faculty Of Science Damietta*,Faculty Of Medicine Zagazig \\ University**, Faculty Of Medicine Mansoura University***
}

\begin{abstract}
The study was carried out on 50 allergic asthmatic children in rural district in sherbin,dakahlia and received their medication and immunotherapy from clinical immunology unit,zagazig university hospital.fifty patients were divided into 40 patients as active immunotherapy group and 10 patients as control group.

Immunotherapy was administered according to preseasonal schedule six month before pollen season.all patients have positive skin prick test and were evaluated clinically and immunologically pre and post immunotherapy (for six month),
\end{abstract}

\section{Results}

significant decrease in total serum IgE level $\mathrm{P}=0.018(\mathrm{p}<0.05)$ and significant increase in total serum $\operatorname{IgG}(\mathrm{P}<0.001)$ after immunotherapy in all patients So immunotherapy is considered line of treatment for allergic patients.

Key words

Asthma,Chlidren,Total IgE,Total IgG.

\section{Introduction}

Asthma and allergies are among the most chronic disease,asthma is reported to be the most frequent cause of childhood disability(Martin Munoz, 2004)

Pollen allergy

Life-threatening reactions may be observed with high quality extracts and exceptional deaths have been reported (Bousquet et al., 1994a). The rate of systemic reactions is greater with standardized pollen extracts than with either non-standardized extracts or high molecular weight preparations (Bousquet et al., 1989,Grammer et al., 1986and Grammer et al., 1987). However, using SIT with care it has been shown that standardized extract can be used safely (Hejjaoui et al., 1992).

Allergen immunotherapy in children is effective and well tolerated.It has been shown to prevent the new onest of allergen sensitivities in monosensitized patients as well as progression from allergic rhinitis to asthma(lind et al.,2010)
Immunotherapy induces a switch of the preferential differentiation of native $t$ helper cell from $\mathrm{TH} 2$ type effector cells to TH1 type cells(Till et al.,2004)

- Allergen immunotherapy works like a vaccine. Patients receiving allergen

immunotherapy are injected with increasing amounts of an allergen over several months. The body responds to the injected amounts of the allergen by developing an immunity or tolerance to it. As a result, allergy symptoms can be decreased or minimized when the patient is exposed to that allergen in the future.

- Immunotherapy acts by modifying $\mathrm{T}$ cell responses either by immune derivation (increase in $\mathrm{Th}_{0} / \mathrm{Th}_{1}$ ) or $\mathrm{T}$ cell energy (decrease $\mathrm{Th}_{2} / \mathrm{Th}_{1}$ ) or more likely both, depending on a number of factors including the nature of the allergen, the allergen dose, adjuvants used.

- Shortly after initiation of 
immunotherapy there is an increase in CD4+CD25+ regulatory $\mathrm{T}$ Iymphocytes secreting IL-10 and TGF-B

- Associated with immunologic tolerance, defined as a long-lived decrease in allergen-specific T-cell responsiveness. With continued immunotherapy there is some warning of this response and immune deviation from $\mathrm{Th}_{2}$ to $\mathrm{Th}_{1}$ cytokine response to the administered allergen predominates.

- Immune deviation from a $\mathrm{Th}_{2}$ in favor of $\mathrm{aTh}_{1}$ cytokine profile. Data indicate that increases in production of IL-12, a strong inducer of TH1responses, may contribute to this shift(lind et al.,2010)

- During conventional immunotherapy serum IgE concentrations initially rise and gradually fall to normal over months(Lichtenstein,1973) .

- An increase in serum allergen-specific IgG levels, particularly of the IgG4 isotope, has also been associated with immunotherapy..

- Blocking antibody theory (Golden et al.,1982) IgG compete with IgE for allergen binding thereby blocking $\mathrm{IgE}$ dependent activation of mast cell .

\section{Patients and Methods:}

Fifty extrinsic asthmatic children sensitive to grass pollen were enrolled in this study (30male and 20 female).Their age ranged from 5-12years(mean8.5years).the fifty patients were divided into 40 patients as active immunotherapy group and 10 patients as control group.All patients lived in rural district in sherbin,dakahlia and received their medication and immunotherapy from allergy and clinical immunology unit,zagazig university hospital.All patients have positive skin prick test to grass pollen.Clinical and immunological evaluation was performed to every patient.Clinical evaluation include symptoms ,medication score and peak expiratory flow rate.
Immunological evaluation include skin test,determination of total serum IgE by ELISA, and total serum IgG by ELISA (radial immunodiffusion method)

\section{Determination of total serum IgE (Silva et al.,2001): \\ heparinized plasma from patients were} collected and stored at $20 \mathrm{c}^{\circ}$ until the time of assay. The quantizyme immunoassay kit was used(Silva et al.,2001)

Sample preparation(dilute patient sample $1 / 5$ with normal saline)

1-Add 50 of IgE zero calibration standard to zero tubes.

2- Add 50 of undiluted $\operatorname{IgE}$ calibration standards and control to the appropriately labeled tubes.

3- Add 50 of each diluted sample to the appropriate labeled tubes.

4- Add 200 of IgE zero calibration standard to all tubes .

5- Mix reagents in tubes thoroughly by vortexing.

6- Incubate all tubes one hour at $37 \mathrm{c}^{\circ} \pm 2 \mathrm{c}^{\circ}$.

7- Wash all tubes 3 times with 2000 of normal saline. Aspirate

thoroughly after each wash.

8- Add 250 of total IgE conjugate to all tubes.

9- Incubate all tubes one hour at $37 \mathrm{c}^{\circ} \pm 2 \mathrm{c}^{\circ}$. 10- Wash 3 times as described in step 7.

11- Add 250 of prepared substrate working solution to each tube in carefully timed intervals.

12- Incubate all tubes one hour at room temperature .

13- Add 1000 of stopping solution to each tubes at the same time interval as the addition of the substrate working solution.

14- Mix reagents in tubes thoroughly by vortexing

15-Read absorbance on ELISA wavelength reader at $450 \mathrm{~nm}$.

\section{2- Determination of serum IgG level by ELISA(radial immunodiffusion method)(Mancini et al., 1965):}

By using single radial immunodiffusion method (Kallestad Endoplate IgG) .

This technique based on the fact that antigen - antibody interaction is manifested 
as precipitation ring and can be visualized in gels such as agar. If an antigen is placed in a well within antibody containing agar gel, it diffuses into the agar. Then diameter of precipitation ring becomes manifested around the antigenic well. The diameter of precipitation ring is directly related to the concentration of the antigen.

Procedures:

- The immunodiffusion plate was opened and allowed to remain uncovered at room temp. for 5 minutes ( to allow evaporation of any water condensation ) .

- 5 microL of patient's serum was dispensed onto wells and the plate was covered tightly and incubated for 48 hours at room temp.

- After the diffusion time had elapsed, the diameter of each precipitation ring was measured using the magnifying lens against black ground.

- The corresponding concentration of the antigen ( $\operatorname{IgG}$ ) was measured from a standard table for conversion of ring diameter.

\section{Statistical analysis:}

The statistical analysis was done using IBM compatible computer using the SPSS / PC + statistical package (SPSS Inc. Chicago, IL) The statistical methods were done for the data of this work according to (Barnett, 1979).

\section{Results}

We recruited 50 patients, 40 patients in the active treatment group (group A) and 10 patients as control group (group B).

The results of the study are shown in the following tables.

Table (1): Demographic data of the studied groups.

\begin{tabular}{|c|c|c|c|c|}
\hline & $\begin{array}{l}\text { Cases } \\
(\mathrm{N}=40)\end{array}$ & $\begin{array}{l}\text { Control } \\
(\mathrm{N}=10)\end{array}$ & $\begin{array}{l}\text { Test of } \\
\text { sig. }\end{array}$ & $\mathrm{P}$ \\
\hline $\begin{array}{l}\text { Age (years) } \\
\mathrm{X} \pm \mathrm{SD} \\
\text { (Range) }\end{array}$ & $\begin{array}{r}7.37 \pm 2.8 \\
(4-12)\end{array}$ & $\begin{array}{l}7.1 \pm 2.8 \\
(4-12)\end{array}$ & $\mathrm{T}=0.77$ & $\begin{array}{l}0.28 \\
\text { N.S. }\end{array}$ \\
\hline $\begin{array}{l}\text { Gender } \\
\text { Male } \\
\text { Female }\end{array}$ & $\begin{array}{l}\text { No\% } \\
2460.0 \\
1640.0\end{array}$ & \begin{tabular}{|cc} 
No. $\%$ \\
6 & 60.0 \\
4 & 40.0
\end{tabular} & $\mathrm{X} 2=0.0$ & $\begin{array}{l}1.0 \\
\text { N.S. }\end{array}$ \\
\hline $\begin{array}{l}\text { Duration } \\
\mathrm{X} \pm \mathrm{SD} \\
\text { (Range) }\end{array}$ & $\begin{array}{r}5.4 \pm 3.3 \\
1-12\end{array}$ & $\begin{array}{r}5.2 \pm 3.3 \\
2-12\end{array}$ & $\mathrm{~T}=0.18$ & $\begin{array}{l}0.8 \\
\text { N.S. }\end{array}$ \\
\hline $\begin{array}{l}\text { Family } \\
\text { historv \% of } \\
\text { atopy }\end{array}$ & 40100.0 & 10100.0 & N.S & \\
\hline
\end{tabular}

There is no significant difference as regard age, sex, duration of illness.

$S D=$ standard deviation.

$N=$ number.$\quad$ N.S. $=$ non significant. 
Evaluation the ....

Table (2): Severity of asthma of cases and control before immunotherapy.

\begin{tabular}{|c|c|c|c|c|c|c|}
\hline & \multicolumn{2}{|l|}{ Cases } & \multicolumn{2}{|c|}{ Control } & \multirow[t]{2}{*}{$\mathrm{X} 2$} & \multirow[t]{2}{*}{$\mathrm{p}$} \\
\hline & No. & $\mathrm{O} / \mathrm{O}$ & No. & $\mathrm{O} / \mathrm{O}$ & & \\
\hline Moderate & 23 & 57.5 & 6 & 60.0 & 0.02 & 0.8 \\
\hline Severe & 17 & 42.5 & 4 & 40.0 & N.S. & \\
\hline
\end{tabular}

There is no significant difference between clinical types among cases and control.

Table (3): Symptoms and medication scores of cases and control before immunotherapy.

\begin{tabular}{|l|l|l|c|}
\hline & Cases & Control & $\mathrm{T} p$ \\
\hline Nasal symptoms & $71 \pm 10.5$ & $67 \pm 6.7$ & $\begin{array}{c}1.48>0.05 \\
\text { N.S. }\end{array}$ \\
\hline Bronchial & $23 \pm 5.1$ & $25 \pm 6.1$ & $0.95>0.05$ \\
Symptoms & & N.S. \\
\hline Medication score & $2.1 \pm 0.5$ & $2.05 \pm 0.7$ & $0.2>0.05$ \\
& & & N.S. \\
\hline
\end{tabular}

There is non significant difference in symptom and medication scores between case group and control group before immunotherapy.

Table (4): Immunoglobulin levels before immunotherapy.

\begin{tabular}{|l|l|l|l|l|}
\hline & Cases & Control & T & p \\
& $\mathrm{N}=40$ & $\mathrm{~N}=\mathbf{1 0}$ & & \\
$\mathrm{X} \pm \mathrm{SD}$ & $176.8 \pm 39.0$ & $177.5 \pm 21.9$ & 0.05 & 0.95 \\
$($ Range $)$ & $130-280$ & $155-220$ & & N.S. \\
\hline $\begin{array}{l}\text { IgG } \\
\mathrm{X} \pm \mathrm{SD}\end{array}$ & $1695.7 \pm 642.4$ & $1495 \pm 592.3$ & 0.89 & 0.62 \\
$($ Range $)$ & $900-3000$ & $900-2750$ & & N.S. \\
\hline
\end{tabular}

There is no significant difference between the two groups before immunotherapy. 
Table (5): The relation between the IgE level and the severity of asthma among cases before immunotherapy.

\begin{tabular}{|l|l|l|ll|}
\hline & Moderate & Severe & p \\
\hline $\mathrm{NgE}$ & $\mathrm{N}=23$ & & \\
$\mathrm{X} \pm \mathrm{SD}$ & $149.3 \pm 12.4$ & $213.9 \pm 30.8$ & 9.1 & $<0.001$ \\
\hline Range & & & Sig. \\
\hline Median & $130-170$ & $180-280$ & \\
\hline
\end{tabular}

There is significant increase in the IgE level according to severity among cases before immunotherapy.

Table (6): The relation between the IgG level and the severity of asthma among cases before immunotherapy.

\begin{tabular}{|l|l|l|c|}
\hline & Moderate & Severe & $\mathrm{T} P$ \\
\hline $\mathrm{IgG}$ & & & $10.6<0.001$ \\
$\mathrm{X} \pm \mathrm{SD}$ & $1209.6 \pm 283.5$ & $2271.4 \pm 423.8$ & Sig. \\
\hline Range & $900-2200$ & $1620-3000$ & \\
\hline Median & 1110 & 2200 & \\
\hline
\end{tabular}

There is significant increase in the IgG level according to severity among cases before immunotherapy.

Table (7): The correlation between IgE and clinical parameters before immunotherapy.

\begin{tabular}{|l|l|l|}
\hline & $\mathbf{r}$ & $\mathrm{p}$ \\
\hline Age & -0.63 & $<0.001$ \\
\hline Symptom score & 0.6 & $<0.001$ \\
\hline
\end{tabular}

There is significant positive correlation between IgE level and symptom score while there is significant negative correlation between IgE level and age of the patients. 
Table (8): Correlation between IgG and clinical parameters before immunotherapy.

\begin{tabular}{|l|l|l|}
\hline & $\mathbf{r}$ & $\mathbf{p}$ \\
\hline Age & -0.63 & $<0.001$ \\
\hline Symptom score & 0.7 & $<0.001$ \\
\hline
\end{tabular}

There is significant positive correlation between IgG level and symptom Score while there is significant negative correlation between IgE level and age of the patients.

Table (9): The relation between IgE level and duration of illness before immunotherapy.

\begin{tabular}{|l|l|l|lc|}
\hline & $>5$ years & $<5$ years & T P \\
& $\mathrm{N}=\mathbf{1 8}$ & $\mathrm{N}=22$ & \\
\hline $\mathrm{IgE} \pm \mathrm{SD}$ & $164 \pm 25.1$ & $187.3 \pm 45$ & 1.94 & 0.056 \\
\hline Range & $130-232$ & $135-280$ & & \\
\hline Median & 160 & 190 & & \\
\hline
\end{tabular}

There is no significant difference in IgE level among cases according to duration of illness.

Table (10): IgG level according to duration of illness before immunotherapy.

\begin{tabular}{|l|l|l|l|l|}
\hline & $>5$ years & $<5$ years & T & $\mathrm{p}$ \\
\hline \multirow{2}{*}{$\begin{array}{l}\text { IgG } \\
\text { X } \pm \text { SD }\end{array}$} & $\mathrm{N}=\mathbf{1 8}$ & $\mathrm{N}=22$ & & \\
\hline Range & $1921.8 \pm 672$ & & 206 & 0.01 \\
\hline Median & $1100-3000$ & $1419.4 \pm 491.3$ & Sig. & \\
\hline
\end{tabular}

There is significant relation between IgG level and duration of illness (natural immunotherapy)

Table (11): Symptom and medication scores of cases and control after immunotherapy.

\begin{tabular}{|c|c|c|c|c|}
\hline & $\begin{array}{l}\text { Cases } \\
\mathrm{X} \pm \mathrm{SD}\end{array}$ & $\begin{array}{l}\text { Control } \\
\mathrm{X} \pm \mathrm{SD}\end{array}$ & $\mathrm{T}$ & $\mathrm{P}$ \\
\hline Nasal symptoms & $44.9 \pm 6.5$ & $67 \pm 6.7$ & 9.3 & $\begin{array}{l}<0.001 \\
\text { Sig. }\end{array}$ \\
\hline Bronchial symptoms & $13 \pm 5.1$ & $25 \pm 6.1$ & 5.5 & $\begin{array}{l}<0.001 . \\
\text { Sig }\end{array}$ \\
\hline Medication score & $1.07 \pm 0.3$ & $2.05 \pm 0.7$ & 4.2 & $\begin{array}{l}<0.001 \\
\text { Sig. }\end{array}$ \\
\hline
\end{tabular}

There is significant difference in symptom and medication scores between case group and control group after immunotherapy. 
Table (12): The changes in immunoglobulin levels after immunotherapy.

\begin{tabular}{|l|l|l|l|l|}
\hline & Before & After & $\mathrm{T}$ & $\mathrm{P}$ \\
\hline $\mathrm{IgE}$ & $\mathrm{N}=40$ & & \\
\hline $\mathrm{X} \pm \mathrm{SD}$ & $176.8 \pm 39.0$ & $170.6 \pm 40.4$ & 2.426 & 0.018 \\
\hline (Range) & $130-280$ & $100-250$ & & Sig. \\
\hline IgG & & & & $<0.001$ \\
\hline $\mathrm{X} \pm \mathrm{SD}$ & $1695.7 \pm 642.4$ & $1832.5 \pm 715.9$ & 5.45 & H.S \\
\hline (Range) & $900-3000$ & $1000-3500$ & & \\
\hline
\end{tabular}

There is significant decrease of IgE and sign Increase of IgG after immunotherapy.

Table (13): The IgE level according to severity among cases after immunotherapy.

\begin{tabular}{|l|l|l|l|l|}
\hline \multirow{2}{*}{} & Moderate & Severe & T & P \\
\cline { 2 - 5 } & $\mathrm{N}=23$ & $\mathrm{~N}=17$ & \multirow{2}{*}{35.92} & 0.001 \\
\hline $\mathrm{IgE}$ & & & & \\
\cline { 2 - 5 } $\mathrm{X} \pm \mathrm{SD}$ & $152.2 \pm 13.1$ & $211 \pm 29$ & Sig. & \\
\hline Range & $130-180$ & $180-280$ & & \\
\hline Median & 150 & 195 & & \\
\hline
\end{tabular}

There is significant difference of IgE level according to severity among cases after immunotherapy. 
Table (14): The IgG level according to severity among cases after immunotherapy.

\begin{tabular}{|c|c|c|c|c|}
\hline & Moderate & Severe & $\mathrm{T}$ & $\mathrm{p}$ \\
\hline & $N=23$ & $\mathrm{~N}=17$ & \multirow{2}{*}{9.3} & \multirow{2}{*}{$<0.001$} \\
\hline \multicolumn{3}{|l|}{$\operatorname{IgG}$} & & \\
\hline $\mathrm{X} \pm \mathrm{SD}$ & $1240.4 \pm 301$ & $2311.7 \pm 424$ & \multicolumn{2}{|l|}{ Sig. } \\
\hline Range & $900-2200$ & $1620-3000$ & & \\
\hline Median & 1180 & 2300 & & \\
\hline
\end{tabular}

There is significant difference of IgG level according to severity among cases after immunotherapy.

Table (15): Adverse reactions to immunotherapy:

\begin{tabular}{|l|l|}
\hline Adverse reactions & No. of cases \\
\hline Local reactions. & 15 \\
\hline Urticaria. & 6 \\
\hline Allergic symptoms of eye. & 3 \\
\hline Allergic symptoms of nose. & 5 \\
\hline Anaphylaxis & 0 \\
\hline
\end{tabular}

\section{Discussion:}

In our study there is significant positive correlation between IgE level and asthma severity. Before immunotherapy, $\operatorname{IgE}$ is higher in sever cases than In moderate cases. Furthermore, there is also significant difference in $\mathrm{IgG}$ level according to severity of asthma before immunotherapy (table 5 \& 6). This agreed with Soda et al. (1992) who reported that serum levels of IgG was higher in sever asthmatics than those with mild asthma. This is in agreement with Corrigan and Kay (1990) who found that T-cell activation correlates with the severity of asthma, also Motojima et al. (1995) found a significant difference of the serum IL-2R concentration between patients with severe and moderate asthma.
This can be explained on the basis that allergenic stimulation to the $\mathrm{T}$ lymphocytes results in their activation which can be expressed by more IL-2 R and hence the release of cytokines IL-4 \& IL-5. IL-4 cause the release of more IgE and IL-5 recruits eosinophils to the site of inflammation with release of major basic proteins, PAF and leukotrines. The last 3 substances which are released by eosinophils result in bronchospasm and damage of respiratory epithelium giving more symptoms (Kuo and Leiden, 1999).

Moreover we detected significant decrease in $\operatorname{IgE}$ level and significant increase in $\operatorname{IgG}$ after immunotherapy as shown in (table 12). Our results showed increased IgG level following six months of SIT this in agreement with (Djurup, 1988) who found 
a significant increase in serum specific IgG. Also, it agrees with Frostad et al. (1983) who found that after long term immunotherapy specific IgE shows slow decline.

Michel et al. (1990) concluded that the IgG increased in response to allergen injection immunotherapy is

Called blocking antibody because it successfully competes for antigen with cell bound $\operatorname{IgE}$, thereby reducing

the effective concentration of antigen that can react with mast cell bound $\operatorname{IgE}$, thus interrupting the initial triggering event in the allergic response.

Serum IgE is also altered by immunotherapy in patients undergoing specific immunotherapy, the IgE antibody titer directed against the injected allergen frequently rises initially but then gradually declines (Mc Hugh et al., 1990).

Our study revealed significant difference in IgE and IgG level according to severity among active immunotherapy group after immunotherapy when compared with the same groups before immunotherapy (table $13 \& 14)$.

Several mechanisms have been postulated to account for the clinical effectiveness of immunotherapy.

They include:

- Increased allergen-specific IgG antibody that competes with cell bound IgE for circulating allergen (Djurup, 1988).

- Decreased total serum IgE level and blunted seasonal rises of allergen specific IgE antibody (Eggleston et al., 2004).

- A reduction of in-vitro lymphocyte responsiveness to allergens as

- Generation of allergen - specific Suppressor cells (Gurka and Rocklin, 1988).

- Reduced expression high affinity IL-2 receptors and decreased sensitivity of helper T cells (Hsieh et al., 2003).

- Switch of the preferential of Native T helper cell from TH2- type effector cells to the TH 1- type (Nouri-Aria et al., 2004), and this switch results in

- Inhibition of IL-4 which is a mandatory cytokine for release of $\operatorname{IgE}$ from B cells (Gillis et al., 1989), and thus the activity of mast cells is reduced and results in a decreased release of allergic mediators responsible for allergic symptoms,

-Reduced production of IL-5, the activity of eosinophils is decreased, resulting in less inflammation and destruction (Feria et al., 2004),

- Increased gamma interferon (INFgamma) by THI which has an inhibitory effect on B growth, inhibiting the action of IL-4 and inducing a switch to gamma 4 in immunoglobulin gene, which favors an IgG4 response (Tapia, 2004).

\section{References}

1. Corrigan CJ, Kay AB (1990). CD4 TIymphocyte activation in acute severe asthma. Relationship to disease severity and atopic status. Am Rev Respir Dis; 141 (4 Pt 1): 970-7.

2. Eggleston PA(1997). Allergen-specific immunotherapy in childhood asthma. Curr Opin Pediatr; 9(6): 582-4.

3. Kuo CT, Leiden JM(1999). Transcriptional regulation of $\mathrm{T}$ lymphocyte development and function. Annu Rev Immunol; 17: 14987.

4. McHugh S(1996). Immunological responses to immunotherapy. Clin Exp Allergy; 26(10): 11 01-4.

5. McHugh SM, Lavelle B, Kemeny DM, Patel S, Ewan rw(1990). A placebocontrolled trial of immunotherapy with two extracts of Dermatophagoides pteronyssinus in allergic rhinitis, comparing clinical outcome with changes in antigen-specific $\operatorname{IgE}, \mathrm{IgG}$, and $\mathrm{IgG}$ subclasses. J Allergy Clin Immunol; 86(4 Pt 1): 521-31.

6. Motojima S, Ogata H, Tateishi K, Fukuda T, Makino S, Koseki T, Adachi T, Kihara N(1995). Measurement of serum and sputum eosinophil cationic protein concentrations in asthma. Arerugi; 44(11): 1272-81.

7. Till Sj, Francis jN, Nouri-Aria $K$, Durham SR(2004). Mechanisms of immunotherapy. J Allergy Clin Immunol; 113(6): 1025- 34.

8. Lichtenstein $\mathbf{L} \quad \mathbf{M}$ ,Ishizaka,k;Norman,P.S.,Sobotka,A.K.,Hill,B .M.(1973).IgE antibody measurements in ragweed hay fever.relationship to clinical severity and the results of immunotherapy journal clin.Invest.,52:472-482. 
9. Mancini G, Carbonara AO, Heremans JF(1965).Immunochemical quantitatoin of antigens by single radial immunodiffusion.Immunochemistry;2(3):23554.

10. Cox L , Nelson H,and Lockey $\mathbf{R}$ (2010).Allergen immunotherapy:A practice Parameter Third Update,

11. Munoz M MF(2004).Efficacy of Immunotherapy in treatment of asthma.Allergol Immunopathol(Madr);32(3):133-141.

12. Bousquet and Michel(1994).Considerations for intiating immunotherapy,table In:Immunotherapy Coarse,Funded through an educational grant from ALK

Laboratories;Moday,Feb.24,(1997)The

AAAA\&AAI/CIS joint Meeting Feb.2126(1997)san Francisco,California.

13. Bousquet j,maasch HJ,Hejjaoui A,et al.(1989).Double-blind,placebo-controlled immunotherapy with mixed grass-pollen allergoids.efficacy and safety of ultrafiltration and high-molecular-weight preparations in rhino-conjunctivitis and asthma.J Allergy Clin Immunol., 84:546-56.

14. Golden D B K, Meyer, d.a; KageySobotka, A; Valentine, M.D; Lichtenstein, L.M.(1982). Clinical relevance of the venomspecific immunoglobulin-G antibody level during immunother-pay.J.Allergy Clin. Immunol.,96:489-493.

15. Grammer LC, Shaughessy MA, Berhard MI, et al.(1987). The safey and activity of polymerized ragweed: a doubleblind, placebo-controlled trial in81 patients with ragweed rhinitis. I Allergy Clin Immunol., 80:177-83.

16. Grammer LC, Shaughessy MA,FINKLe SM,Shaughnessy JJ, patterson R.(1986).safty and immunogenitity of immuonotherapy with multiple inhalant sensitivities. J Allergy clin 3 Immunol,77:53-8. 17. Hejjaoui A, Ferrando $\mathbf{R}$, Dhivert $\mathbf{H}$, Michel FB, B,Bousquet J.(1992). Systemic reactions occurring during immunotherapy with standardized pollen extracts.J Allrgy Clin Immunol.,89:925-33.

18. Djurup $\mathbf{R}(1988)$. Immunochemical quantitation of $\mathrm{IgG}$ subclass proteins and $\mathrm{IgG}$ subclass antibodies: status and perspectives. Monogr Allergy; 23: 12-7.

19. Frostad AB, Grimmer 0, Sandvik L, Moxnes A, Aas K(1983). Clinical effects of hyposensitization using a purified allergen preparation from Timothy pollen as compared to crude aqueous extracts from Timothy pollen and a four-grass pollen mixture respectively. Clin Allergy; 13(4): 337-57.

20. McHugh SM, Lavelle B, Kemeny DM, Patel S, Ewan rw(1990). A placebocontrolled trial of immunotherapy with two extracts of Dermatophagoides pteronyssinus in allergic rhinitis, comparing clinical outcome with changes in antigen-specific $\mathrm{IgE}, \mathrm{IgG}$, and $\mathrm{IgG}$ subclasses. J Allergy Clin Immunol; 86(4 Pt 1): 521-31.

21. Gurka G, Rocklin R(1988). Immunologic responses during allergenspecific immunotherapy for respiratory allergy. Ann Allergy; 61(4): 239-45.

22. Ogurusu K, Takahashi K, Soda R, Araki M, Sunami K, Takeda K, Kozuka A, Katagi S, Yamagata K, Kimura 1(1992). Studies on IgG subclass antibodies in adult asthma. 2. Changes in serum antigen specific IgG subclass antibodies for aging and intractability in asthmatics. Arerugi; 41 (1): 7 14.

23. Bousquet J, Godard P, Michel FB(1988). Specific desensitization in 1988. PresseMed; 17(21): 1087-90

24. Gordon J, Millsum MJ, Flores-Romo L, Gillis S(1989). Regulation of resting and cycling human B lymphocytes via surface IgM and the accessory molecules interleukin-4, CD23 and CD40. Immunology; 68(4): 526-31.

25. Huang JL, Chen LC, Yeh KW, Lin SJ, Hsieh KH, Kuo ML (2003). TH1 and TH2 cytokine production among asthmatic children after immunotherapy. J Asthma; 40(3): 273-9.

26. Nouri-Aria KT, Wachholz PA, Francis JN, Jacobson MR, Walker SM, Wilcock LK, Staple SQ, Aalberse RC, Till SJ, Durham SR(2004). Grass pollen immunotherapy induces mucosal and peripheral IL-IO responses and blocking IgG activity. J Immunol; 172(5): 3252-9.

27. Velazquez BL, Segura DL, Barbosa DE, Vazquez MI, Tapia JG, Altamirano sc, Feria AJ(2004). Determination of interleukins and IgG4 in patients with allergic rhinitis with and without immunotherapy. Rev Alerg Mex; 51(4): 139-44. 


\section{تقييم كفاءة العلاج المناعى فى علاج مرضى الربوالشعبى}

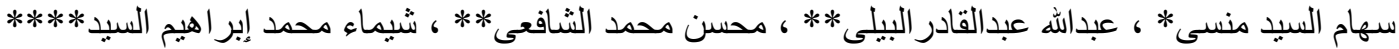

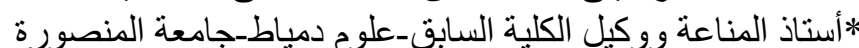

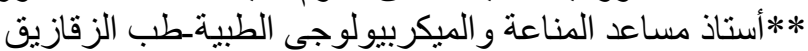

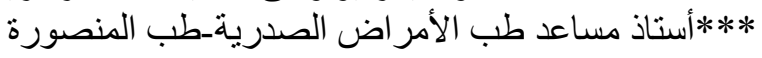

$$
\begin{aligned}
& \text { باحث ماجستيرفى علم الحيوان الأن }
\end{aligned}
$$

وتهدف هذه الدر اسة الى تقييم دور العلاج المناعى بالحقن فى الأطفال المصابين بحساسية الربو

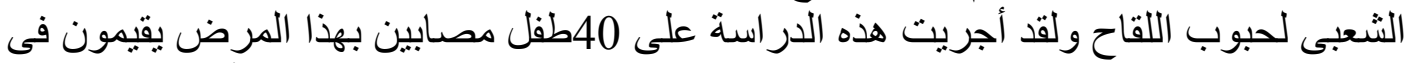

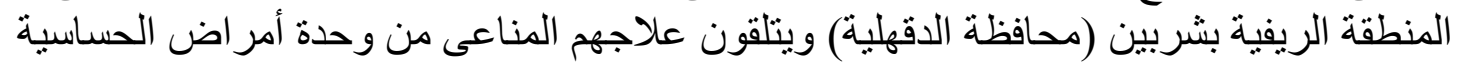

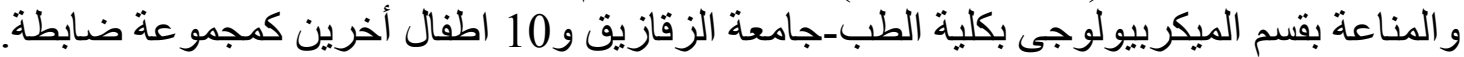

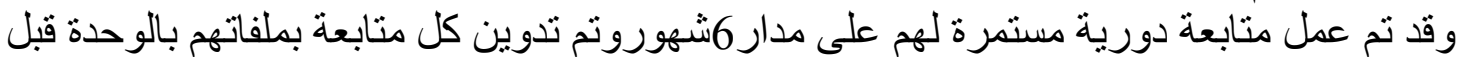

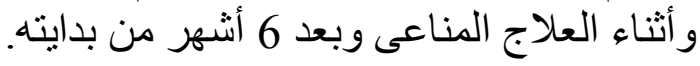
وقد تم عمل الأتى لكل طفل من هؤ لاء الأطفال:

1-الفحص الاكلينكى الثامل متضمنا الأعر اض و الأدوية التى تعاطها وماز ال بتناولها كل طفل

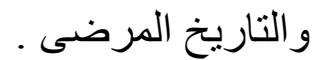

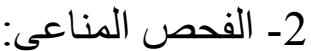

أـ در اسة حساسية جلدية باستخدام التوفرمن المواد المسببة للحساسية من حبوب اللقاح المتاحة

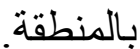



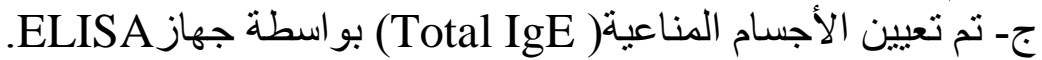
د- تم تعيين الأجسام المناعية(Total IgG) بو اسطة جناعة جهاز .ELISA(radial immunodiffusion method)

وقد خلص هذا البحث الى أن : مجمو عة المرضى التى خضعت للعلاج قد أبدت تحسنا ملحوظا بالقياس إلى المجمو عة الضابطة. 